\title{
The effects of cholera toxin, pertussis toxin, sodium fluoride and $\alpha$-interferon on prostaglandin production by the guinea-pig endometrium*
}

\author{
Caroline M. Leckie and N. L. Poyser \\ Department of Pharmacology, University of Edinburgh Medical School, 1 George Square, \\ Edinburgh EH8 9JZ, UK
}

\begin{abstract}
Summary. The outputs of prostaglandin (PG) F-2 $\alpha, 6$-keto-PGF-1 $\alpha$ and PGE-2 from Day- 7 and Day- 15 guinea-pig endometrium were neither stimulated nor inhibited by cholera toxin and pertussis toxin. This indicates that PG synthesis by guinea-pig endometrium is not controlled by toxin-sensitive G-proteins. Short-term treatment of guinea-pig endometrium in culture with sodium fluoride stimulated PG output, suggesting that endometrial PG synthesis may be regulated by a fluoride-sensitive G-protein. Long-term treatment of guinea-pig endometrium in culture with sodium fluoride inhibited endometrial PG synthesis, and this was due to an inhibition of endometrial protein synthesis. Human $\alpha$-interferon had no inhibitory effect on the outputs of PGF-2 $\alpha, 6$-keto-PGF-1 $\alpha$ and PGE-2 from Day-15 guinea-pig endometrium in culture. It appears that the anti-luteolytic factor secreted by guinea-pig conceptus is not an $\alpha$-interferon and is therefore probably different from ovine trophoblast protein-1.
\end{abstract}

Keywords: cholera toxin; pertussis toxin; fluoride; $\alpha$-interferon; guinea-pig; uterus; prostaglandins

\section{Introduction}

Prostaglandin (PG) F-2 $\alpha$ produced by the uterus is responsible for regression of the corpora lutea in the ovary of several non-primate species, including the guinea-pig (see Horton \& Poyser, 1976; Poyser, 1981). Since PGF-2 $\alpha$ is not stored in the guinea-pig uterus (Poyser, 1972), its release has to be immediately preceded by its synthesis from arachidonic acid. The concentration of free arachidonic acid in the guinea-pig uterus is very low (Leaver \& Poyser, 1981), and so arachidonic acid for PG synthesis has to be released from some bound source. Over $90 \%$ of the total arachidonic acid in the guinea-pig uterus is bound to phospholipid, of which $80 \%$ is present in phosphatidylcholine (PC) and phosphatidylethanolamine (PE; Leaver \& Poyser, 1981). Studies on arachidonic acid turnover in guinea-pig endometrium revealed that $\mathrm{PC}$ and $\mathrm{PE}$, but not phosphatidylinositol (PI), are the probable source of arachidonic acid for increased endometrial PGF-2 $\alpha$ synthesis at the end of the cycle (Ning et al., 1983; Ning \& Poyser, 1984). This implies that activation of phospholipase (PL) A-2, which is present in guinea-pig endometrium in greater amounts towards the end of the cycle (Downing \& Poyser, 1983), is an essential step in PGF-2 $\alpha$ synthesis. In various tissues, PLA-2 is activated by a G-protein which is inhibited by pertussis toxin; hence, pertussis toxin reduces PG synthesis (Burch et al., 1986; Burgoyne et al., 1987; Axelrod et al., 1988; Wang et al., 1988; Nakashima et al., 1988). However, pertussis toxin and cholera toxin enhance PGI-2 synthesis by aortic endothelial cells and PGE-2 synthesis by a murine macrophage cell line, apparently by activating G-proteins (Pirotton et al., 1987; Burch et al., 1988). 
Fluoride, another activator of G-proteins, stimulates PGI-2 synthesis by the rat aorta (Jeremy \& Dandona, 1988). Therefore, the effects of cholera toxin, pertussis toxin and sodium fluoride on PG production by the guinea-pig endometrium have been investigated to see whether G-proteins may be involved.

When animals become pregnant, the luteolytic action of the uterus has to be prevented. In sheep, the embryo produces ovine trophoblast protein-1 (oTP-1) which inhibits uterine PGF-2 $\alpha$ synthesis (Fincher et al., 1986). It has been shown that oTP-1 has approximately $70 \%$ homology with the $\alpha$-interferons (Imakawa et al., 1987; Stewart et al., 1987, 1989; Charpigny et al., 1988), and that human $\alpha$-interferon inhibits PGF- $2 \alpha$ and PGE- 2 synthesis by sheep endometrial cells in culture (Salamonsen et al., 1988). The guinea-pig conceptus secretes an anti-luteolytic factor which inhibits endometrial PGF-2 $\alpha$ synthesis (see Poyser, 1984) and, therefore, may belong to the group of $\alpha$-interferons. Consequently, the effect of human $\alpha$-interferon on PG synthesis by guinea-pig endometrium has been studied.

\section{Materials and Methods}

Virgin guinea-pigs weighing $700-950 \mathrm{~g}$ were examined daily and a vaginal smear was taken when the vagina was perforate. Day 1 of the cycle was recorded as the day preceding the post-ovulatory influx of leucocytes when cornification was at a maximum. All guinea-pigs had exhibited at least 2 cycles of normal length before being used on Day 7 or Day 15 of the cycle. The uterus was removed, and small pieces of endometrium were cultured in $4 \mathrm{ml}$ Medium 199 (plus Earle's salts, and supplemented with glutamine, amphotericin B and kanamycin) for periods up to $24 \mathrm{~h}$ as described previously (Riley \& Poyser, 1989). The endometrium was subjected to 'treatments' as outlined in Exps 1-3. In Exps 1 and 2 after culture, the pieces of endometrium were dried by placing in an oven for $24 \mathrm{~h}$ at $37^{\circ} \mathrm{C}$. The samples of culture medium obtained were stored at $-20^{\circ} \mathrm{C}$ before being assayed, without extraction, for PGF-2 $\alpha$, 6-keto-PGF-1 $\alpha$ and PGE-2. Equivalent volumes of culture medium were included in the 'standard' PG solutions used in each assay. Tissue and culture medium obtained in Exp. 3 were used for measuring protein synthesis.

Experiment 1: effects of cholera toxin, pertussis toxin and sodium fluoride on endometrial PG output. In Exp. 1(a), 14 dishes of endometrium (12-15 mg/dish) were prepared from each uterus from 5 Day-7 and 5 Day-15 guinea-pigs. Pairs of dishes were treated with one of the following: cholera toxin $(10$ and $100 \mathrm{ng} / \mathrm{ml})$; pertussis toxin $(10$ and $100 \mathrm{ng} / \mathrm{ml}$ ); $10 \mathrm{~mm}$-sodium fluoride; $0.16 \mathrm{~mm}$-dithiothreitol (reagent control); no treatment (control). The cholera toxin and pertussis toxin had been incubated at $37^{\circ} \mathrm{C}$ for $30 \mathrm{~min}$ with dithiothreitol $(12.5 \mathrm{~mm})$ before addition to the dishes in order to keep their sulphide groups in the reduced state for activation of ADP-ribosyltransferase. Consequently, the dishes containing cholera toxin and pertussis toxin also contained $0.16 \mu \mathrm{m}$-dithiothreitol. The endometrium was cultured for up to $24 \mathrm{~h}$, and the culture medium was replaced with fresh medium containing the same treatments every $8 \mathrm{~h}$.

In Exp. 1(b), 10 dishes of endometrium (12-15 mg/dish) were prepared from each uterus obtained from 5 Day-7 guinea-pigs. Pairs of dishes were treated with one of the following: cholera toxin ( 10 and $100 \mathrm{ng} / \mathrm{ml})$, sodium fluoride ( 2 and $10 \mathrm{~mm}$ ); no treatment (control). The endometrium was cultured for $1 \mathrm{~h}$.

Experiment 2: effects of a-interferon, sodium fluoride and indomethacin on endometrial PG output. In Exp. 2(a), 12 dishes of endometrium $(12-15 \mathrm{mg} / \mathrm{dish})$ were prepared from each uterus obtained from 5 Day- 15 guinea-pigs. Pairs of dishes were treated with one of the following: human $\alpha$-interferon $(5$ and $25 \mathrm{U} / \mathrm{ml})$; sodium fluoride ( 2 and $10 \mathrm{~mm}$ ); indomethacin $(2 \mu \mathrm{g} / \mathrm{ml}$; control inhibitor); no treatment (control). The endometrium was incubated for $24 \mathrm{~h}$, and the culture medium was replaced with fresh medium containing the same treatments every $6 \mathrm{~h}$.

In Exp. 2(b), Exp. 2(a) was repeated using $\alpha$-interferon at concentrations of 500 and $2500 \mathrm{U} / \mathrm{ml}$ instead of 5 and $25 \mathrm{U} / \mathrm{ml}$.

Experiment 3: effect of sodium fluoride on endometrial protein synthesis. Six dishes of endometrium ( $25-30 \mathrm{mg} / \mathrm{dish})$ were prepared from each uterus obtained from 5 Day-15 guinea-pigs. Each dish contained $10 \mu \mathrm{Ci}\left[{ }^{3} \mathrm{H}\right]$ leucine and pairs of dishes were treated with one of the following treatments: sodium fluoride ( 2 and $10 \mathrm{mM})$; no treatment (control). The endometrium was cultured for $24 \mathrm{~h}$, and the amounts of $\left[{ }^{3} \mathrm{H}\right]$ leucine incorporated into endometrial secreted and cellular proteins were measured by methods described previously (Riley \& Poyser, 1989).

Details of radioimmunoassays. PGF-2 $\alpha, 6-k e t o-P G F-1 \alpha$ and PGE- 2 were measured using antibodies raised in this laboratory and whose cross-reactivities have been reported elsewhere (Poyser, 1987). The inter-assay and intra-assay coefficients for the three assays were $<12 \%$. The limits of detection were $30-40 \mathrm{pg}$ per assay tube for each assay.

Sources of material. Cholera toxin, pertussis toxin, dithiothreitol, and human $\alpha$-interferon (lymphoblastoid; $1 \times 10^{7}$ International Reference Units/mg protein) were purchased from Sigma Chemical Co., Poole, Dorset, UK: sodium fluoride was purchased from Fison's Scientific Apparatus, Loughborough, Leics, UK; $\left[{ }^{3} \mathrm{H}\right]$ leucine (sp; act. 
$160 \mathrm{Ci} / \mathrm{mmol}$ ) was purchased from Amersham International Ltd, Bucks, UK; indomethacin was supplied by Merck, Sharpe \& Dohme Ltd, Hoddesdon, Herts, UK.

Statistical tests. Changes in the output of PGs with time were analysed by Duncan's multiple range test or, if the variances of the groups were significantly different by the variance ratio $F$ test, by a modified $t$ test for unequal variances. Differences between treated and control groups were analysed by Student's $t$ test or, if the variances of the two groups were significantly different by the variance ratio $F$ test, by a modified $t$ test for unequal variances.

\section{Results}

In Exps 1 and 2 the results are expressed as per unit dry weight of tissue, while in Exp. 3 the results are expressed as per unit wet weight of tissue. The control outputs of PGF-2 $\alpha, 6-k e t o-P G F-1 \alpha$ and PGE-2 from Day-15 endometrium and of 6-keto-PGF-1 $\alpha$ from Day-7 endometrium significantly $(P<0.05)$ declined during $24 \mathrm{~h}$ of culture. The control output of PGF-2 $\alpha$ from Day-7 endometrium significantly $(P<0.05)$ increased while the control output of PGE-2 from the same tissue did not significantly change during 24 h of culture (Figs 1, 2, 4 \& 5).

\section{Experiment 1: effects of cholera toxin, pertussis toxin and sodium fluoride on endometrial PG output}

In Exp. 1(a), dithiothreitol (0.16 mM) had no significant effect (data not shown) on endometrial output of any of the 3 PGs measured during any of the 3 successive 8 -h periods of culture,
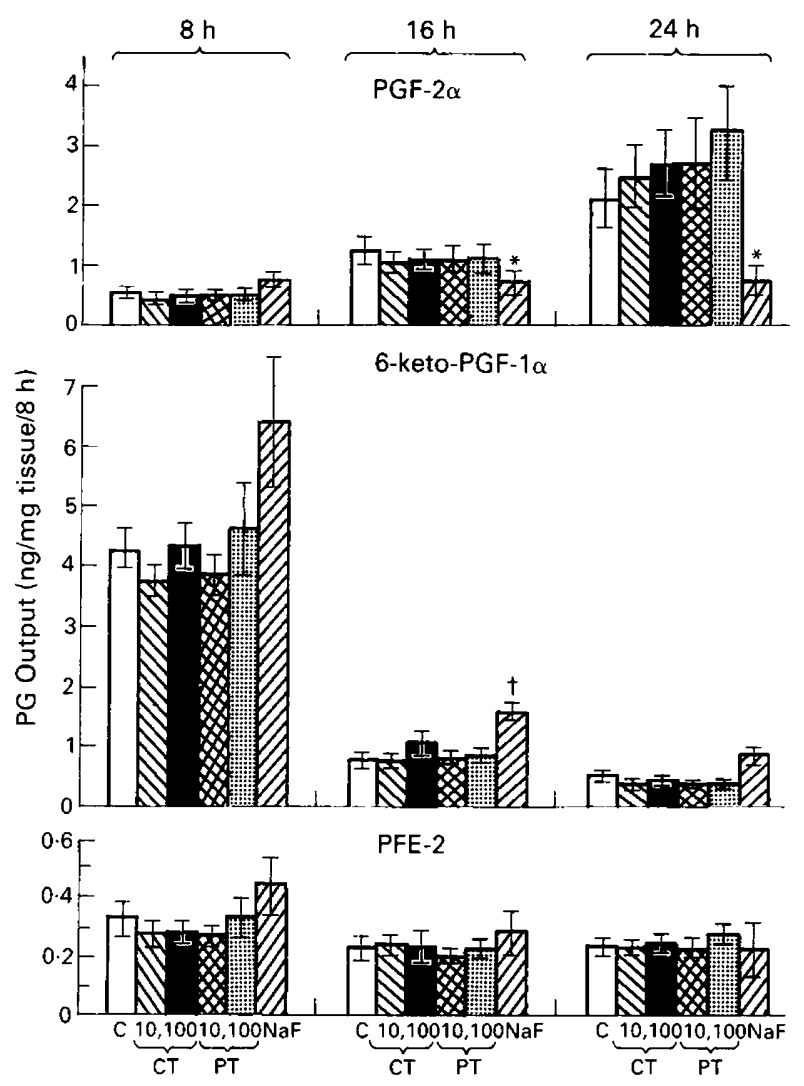

Fig. 1. Effects of cholera toxin (CT; 10 and $100 \mathrm{ng} / \mathrm{ml})$, pertussis toxin (PT; 10 and $100 \mathrm{ng} / \mathrm{ml})$ and sodium fluoride (NaF; $10 \mathrm{~mm}$ ) on mean ( \pm s.e.m., $n=10$ ) outputs of prostaglandin (PG) F-2 $\alpha, 6$-keto-PGF-1 $\alpha$ and PGE-2 from Day-7 guinea-pig endometrium cultured for $24 \mathrm{~h}$ and sampled every $8 \mathrm{~h}$. *Significantly $(P<0.05)$ lower than the corresponding control (C) value for the same $\mathrm{PG}$ at the same time. + Significantly $(P<0.05)$ higher than the corresponding control (C) value for the same $P G$ at the same time. 


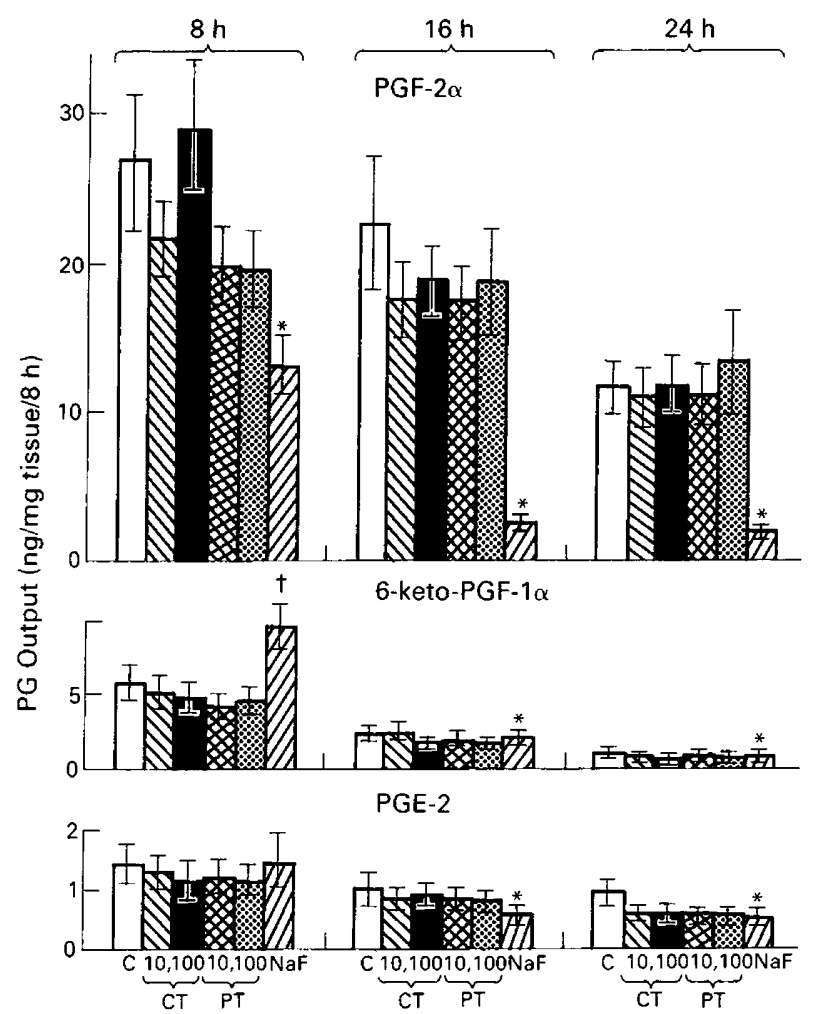

Fig. 2. Effects of cholera toxin (CT; 10 and $100 \mathrm{ng} / \mathrm{ml})$, pertussis toxin (PT; 10 and $100 \mathrm{ng} / \mathrm{ml})$ and sodium fluoride $(\mathrm{NaF} ; 10 \mathrm{~mm}$ ) on mean ( \pm s.e.m., $n=10$ ) outputs of prostaglandin (PG) F-2 $\alpha, 6$-keto-PGF-1 $\alpha$ and PGE-2 from Day-15 guinea-pig endometrium cultured for $24 \mathrm{~h}$ and sampled every $8 \mathrm{~h}$. *Significantly $(P<0.05)$ lower than the corresponding control (C) value for the same $P G$ at the same time. $千$ Significantly $(P<0.05)$ higher than the corresponding control (C) value for the same PG at the same time.

indicating that dithiothreitol alone does not interfere with PG synthesis. Cholera toxin and pertussis toxin (10 and $100 \mathrm{ng} / \mathrm{ml}$ ) had no significant effects on the outputs of PGF-2 $\alpha, 6-k e t o-P G F-1 \alpha$ and PGE-2 from Day-7 and Day-15 guinea-pig endometrium in culture for $24 \mathrm{~h}$ (Figs 1 and 2). Sodium fluoride $(10 \mathrm{~mm})$ tended to increase the outputs of PGF-2 $\alpha, 6-k$ to-PGF-1 $\alpha$ and PGE-2 from Day-7 endometrium after $8 \mathrm{~h}$ of culture, and this stimulation was significant $(P<0.05)$ for 6keto-PGF-1 $\alpha$ after $16 \mathrm{~h}$ of culture (Fig. 1). However, $10 \mathrm{~mm}$-sodium fluoride significantly $(P<0.05)$ inhibited PGF-2 $\alpha$ output from Day-7 endometrium after 16 and 24 h of culture (Fig. 1). Sodium fluoride $(10 \mathrm{~mm})$ significantly $(P<0.05)$ inhibited PGF-2 $\alpha$ output after $8 \mathrm{~h}$, and PGF-2 $\alpha$ and PGE-2 outputs after 16 and $24 \mathrm{~h}$ of culture from Day-15 endometrium (Fig. 2). The output of 6-keto-PGF-1 $\alpha$ from Day-15 endometrium was significantly $(P<0.05)$ increased by sodium fluoride (10 mM) after $8 \mathrm{~h}$ of culture (Fig. 2).

In Exp. 1(b), sodium fluoride $(10 \mathrm{~mm})$ significantly $(P<0.05)$ increased the outputs of PGF-2 $\alpha$, 6-keto-PGF- $1 \alpha$ and PGE-2 from Day-7 guinea-pig endometrium cultured for $1 \mathrm{~h}$ (Fig. 3). Cholera toxin $(10$ and $100 \mathrm{mg} / \mathrm{ml})$ and sodium fluoride $(2 \mathrm{~mm})$ had no effect, except that 2 mm-sodium fluoride significantly $(P<0.05)$ increased the output of 6-keto-PGF-1 $\alpha$ (Fig. 3).

\section{Experiment 2: effects of $\boldsymbol{\alpha}$-interferon, sodium fluoride and indomethacin on endometrial PG output}

Indomethacin $(2 \mu \mathrm{g} / \mathrm{ml})$ significantly $(P<0.05)$ inhibited the outputs of PGF-2 $\alpha$, 6-ketoPGF-1 $\alpha$ and PGE-2 from Day-15 endometrium after $6,12,18$ and $24 \mathrm{~h}$ of culture (Figs 4 \& 5). 

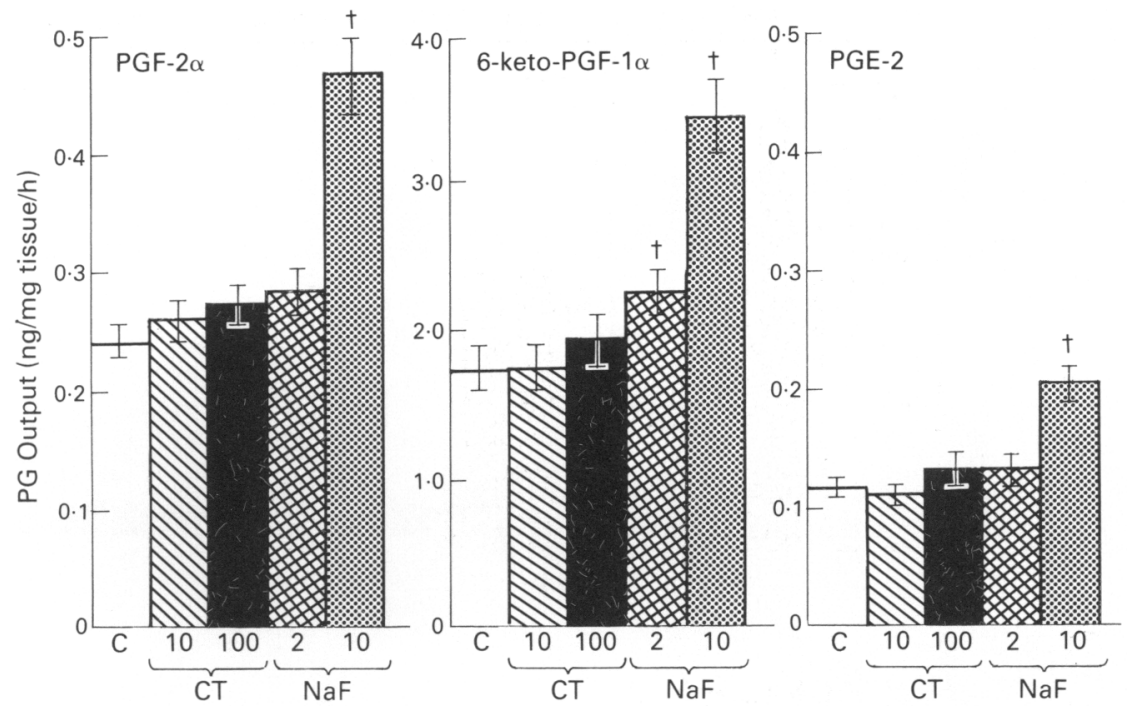

Fig. 3. Effects of cholera toxin (CT; 10 and $100 \mathrm{ng} / \mathrm{ml})$ and sodium fluoride (NaF; 2 and $10 \mathrm{~mm})$ on mean ( \pm s.e.m., $n=10$ ) outputs of prostaglandin (PG) F-2 $\alpha, 6$-keto-PGF- $1 \alpha$ and PGE-2 from Day-7 guinea-pig endometrium cultured for $1 \mathrm{~h}$. †Significantly $(P<0.05)$ higher than the corresponding control $(\mathrm{C})$ value for the same PG.

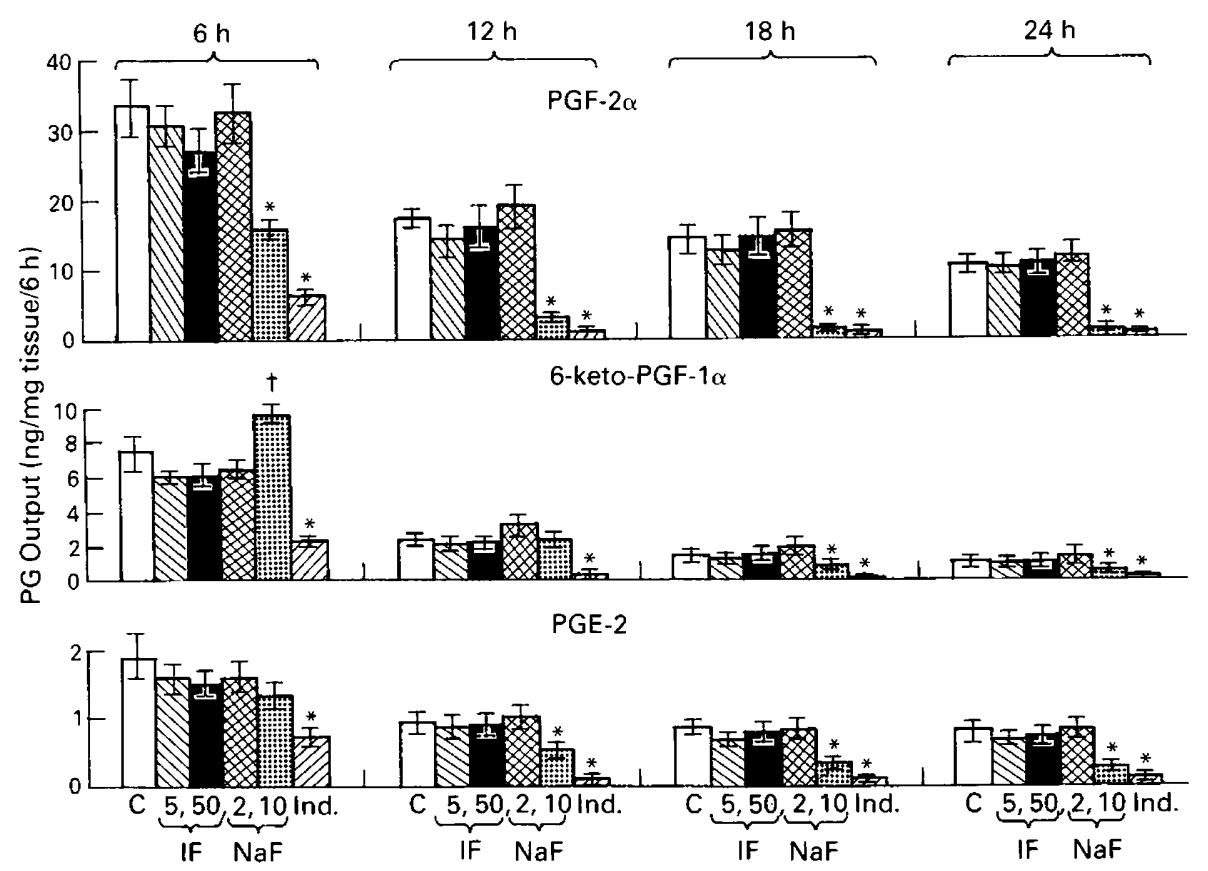

Fig. 4. Effects of human $\alpha$-interferon (IF; 5 and $50 \mathrm{U} / \mathrm{ml}$ ), sodium fluoride (NaF; 2 and $10 \mathrm{~mm}$ ) and indomethacin (Ind.; $2 \mu \mathrm{g} / \mathrm{ml}$ ) on mean ( \pm s.e.m., $n=10$ ) outputs of prostaglandin (PG) F-2 $\alpha, 6-k e t o-P G F-1 \alpha$ and PGE-2 from Day-15 guinea-pig endometrium cultured $24 \mathrm{~h}$ and sampled every $6 \mathrm{~h}$. *Significantly $(P<0.05)$ lower than the corresponding control (C) value for the same $P G$ at the same time. $†$ Significantly $(P<0.05)$ higher than the corresponding control (C) value for the same PG at the same time. 


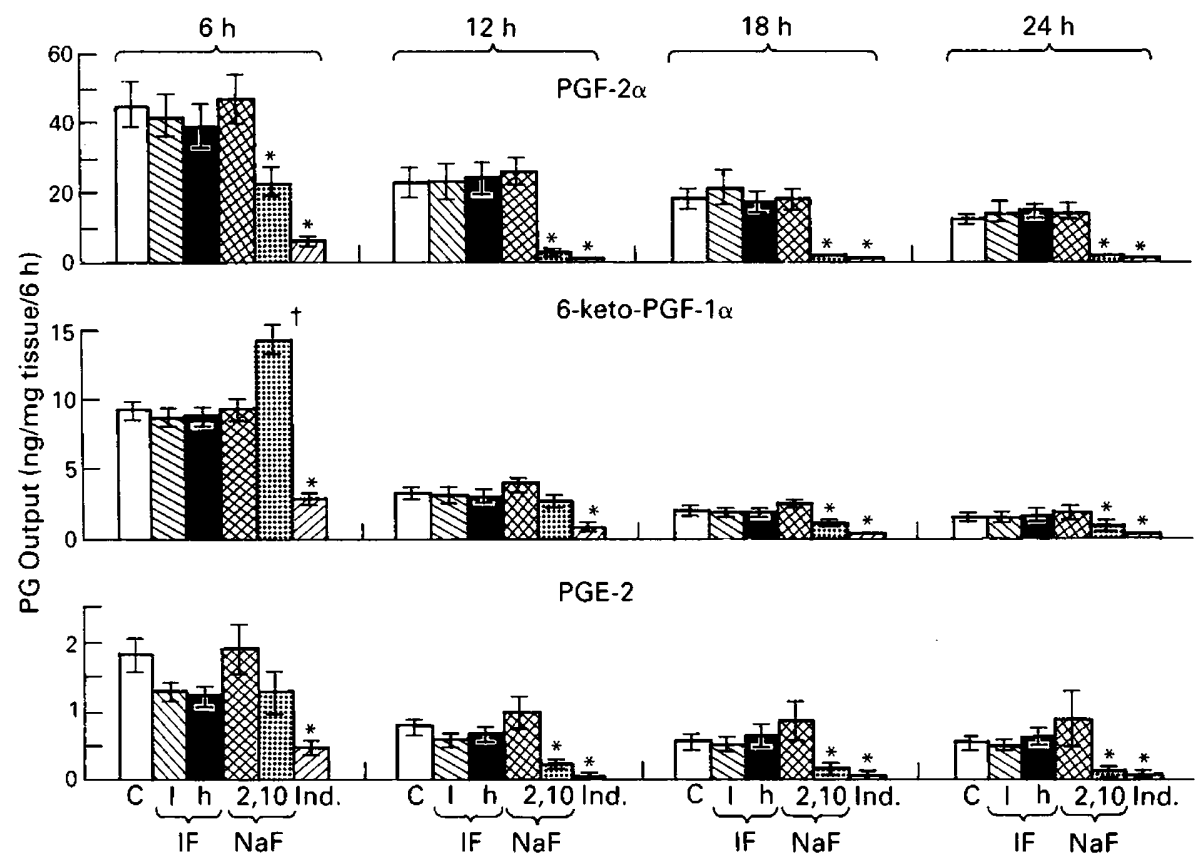

Fig. 5. Effects of human $\alpha$-interferon (IF; $1=500 \mathrm{U} / \mathrm{ml}, \mathrm{h}=2500 \mathrm{U} / \mathrm{ml}$ ), sodium fluoride (NaF; 2 and $10 \mathrm{~mm}$ ) and indomethacin (Ind.; $2 \mu \mathrm{g} / \mathrm{ml}$ ) on mean $( \pm$ s.e.m., $n=10$ ) outputs of prostaglandin (PG) F-2 $\alpha$, 6-keto-PGF-1 $\alpha$ and PGE-2 from Day-15 guinea-pig endometrium cultured for $24 \mathrm{~h}$ and sampled every $6 \mathrm{~h}$. ${ }^{*}$ Significantly $(P<0.05)$ lower than the corresponding control (C) value for the same PG at the same time. †Significantly $(P<0.05)$ higher than the corresponding control $(C)$ value for the same $P G$ at the same time.

Table 1. Effects of sodium fluoride (NaF; 2 and $10 \mathrm{~mm})$ on mean ( \pm s.e.m., $n=10$ ) amounts (d.p.m./mg tissue $/ 10^{6}$ standard disintegrations added) of $\left[{ }^{3} \mathrm{H}\right]$ leucine incorporated into cellular and secreted proteins by Day-15 guinea-pig endometrium cultured for $24 \mathrm{~h}$

\begin{tabular}{lccc}
\hline \multirow{2}{*}{$\begin{array}{l}\text { Type of } \\
\text { protein }\end{array}$} & \multicolumn{3}{c}{$\left[{ }^{3} \mathrm{H}\right]$ leucine incorporation } \\
\cline { 2 - 4 } & Control & $2 \mathrm{~mm}-\mathrm{NaF}$ & $10 \mathrm{mM}-\mathrm{NaF}$ \\
\hline Cellular & $2397 \cdot 2 \pm 277 \cdot 4$ & $2516 \cdot 6 \pm 345 \cdot 1$ & $54 \cdot 9 \pm 7.0 \dagger$ \\
Secreted & $179.2 \pm 19 \cdot 8$ & $172 \cdot 2 \pm 21 \cdot 4$ & $16 \cdot 6 \pm 3.2 \dagger$ \\
\hline
\end{tabular}

$\dagger$ Significantly $(P<0.05)$ lower than the corresponding control value for the same type of protein.

Human $\alpha$-interferon (5-2500 U/ml) had no effect on the outputs of PGF-2 $\alpha, 6-k$ to-PGF-1 $\alpha$ and PGE-2 from Day-15 endometrium in culture for $24 \mathrm{~h}$ after any time period studied (Figs $4 \& 5$ ). Sodium fluoride $(10 \mathrm{~mm}$ but not $2 \mathrm{~mm})$ significantly $(P<0.05)$ inhibited PGF-2 $\alpha$ output after $6 \mathrm{~h}$, PGF- $2 \alpha$ and PGE-2 outputs after $12 \mathrm{~h}$, and PGF-2 $\alpha$, 6-keto-PGF- $1 \alpha$ and PGE-2 outputs after 18 and $24 \mathrm{~h}$ from Day-15 endometrium in culture (Figs $4 \& 5$ ). Sodium fluoride ( $10 \mathrm{~mm}$ but not $2 \mathrm{~mm}$ ) significantly $(P<0.05)$ stimulated 6-keto-PGF-1 $\alpha$ output from Day-15 endometrium after $6 \mathrm{~h}$ of culture (Figs 4 \& 5). 


\section{Experiment 3: effect of sodium fluoride on endometrial protein synthesis}

Sodium fluoride $(10 \mathrm{~mm}$ but not $2 \mathrm{~mm})$ significantly $(P<0.01)$ inhibited by over $90 \%$ the amounts of $\left[{ }^{3} \mathrm{H}\right]$ leucine incorporated into cellular and secreted proteins by Day-15 guinea-pig endometrium in culture for $24 \mathrm{~h}$ (Table 1).

\section{Discussion}

By comparing Figs 1 and 2, the outputs of PGF-2 $\alpha$, PGE-2 and 6-keto-PGF- $1 \alpha$ during the first $8 \mathrm{~h}$ period of culture are 48.7-, 4-5- and 1·3-fold higher from Day-15 endometrium than from Day-7 endometrium, respectively. These findings agree with those of a previous study (Riley \& Poyser, 1989), and the changes are not due to differences in metabolism since PG metabolism by the guineapig uterus is low (Poyser, 1979). The presence of indomethacin in the culture medium greatly inhibited the output of all 3 PGs, indicating that PG synthesis by and secretion from the guineapig endometrium occurred during tissue culture. Consequently, the preferential stimulation of endometrial PGF-2 $\alpha$ synthesis in vivo from about Day 11 of the cycle (Blatchley et al., 1972), by oestradiol acting on a progesterone-primed uterus (Poyser, 1983), is maintained in tissue culture in the absence of steroids.

Cholera toxin and pertussis toxin, in concentrations which normally influence G-protein activity, had no effect on the outputs of PGF-2 $\alpha$, PGE-2 and 6-keto-PGF-1 $\alpha$ from Day-7 and Day-15 guinea-pig endometrium. It therefore appears that toxin-sensitive G-proteins are not involved in the processes which control PGF-2 $\alpha$ synthesis in guinea-pig endometrium.

Sodium fluoride ( $10 \mathrm{~mm}$ but not $2 \mathrm{mM}$ ) had opposite effects on endometrial PG production. In the short term, sodium fluoride stimulated endometrial PG output but, in the longer term, its inhibitory effect prevailed. The inhibitory effect of sodium fluoride was greater for PGF-2 $\alpha$ and PGE-2 than for 6-keto-PGF-1 $\alpha$, and so the stimulatory effect of sodium fluoride lasted longer for 6-keto-PGF-1 $\alpha$ than for PGF-2 $\alpha$ and PGE-2. The inhibitory effect of sodium fluoride was probably due to it inhibiting endometrial protein synthesis, since in a previous study (Riley \& Poyser, 1989) actinomycin $\mathrm{D}$, puromycin and cycloheximide inhibited protein synthesis and prostaglandin synthesis by guinea-pig endometrium, indicating that continued protein synthesis is necessary for continued PG synthesis. The present study provides further evidence for the proposal (Poyser, 1984) that oestradiol stimulates the synthesis of a protein which on a progesterone-primed uterus, 'switches on' PGF-2 $\alpha$ synthesis in guinea-pig endometrium. The fact that sodium fluoride initially stimulated endometrial PG synthesis, whereas cholera and pertussis toxins had no effect, raises the possibility that there is an intermediary G-protein controlling PG synthesis which is fluoridesensitive and toxin-insensitive. Activation of PLA-2 and stimulation of PGE-2 formation by Swiss $3 \mathrm{~T} 3$ fibroblast cells in response to bradykinin is mediated by a pertussis toxin-insensitive G-protein (Burch \& Axelrod, 1987). Furthermore, in these fibroblast cells, cycloheximide inhibited bradykinin-induced PGE-2 formation, indicating that bradykinin causes the synthesis of the G-protein, or of another protein which stimulates the G-protein or is acted upon by the Gprotein. A similar sequence of events in response to oestradiol may occur in the guinea-pig endometrium. Further study is therefore required into how sodium fluoride stimulates endometrial PG synthesis.

Human $\alpha$-interferon combines with the same binding sites as oTP-1 in the sheep endometrium (Stewart et al., 1987), and inhibits PGF-2 $\alpha$ and PGE-2 output from ovine endometrial cells (obtained from oestrogen and progesterone-treated, ovariectomized sheep) in culture (Salamonsen et al., 1988). However, human $\alpha$-interferon, in concentrations up to 500 times greater than those which were effective on ovine endometrial cells, had no effect on PG output from Day-15 guineapig endometrium in culture. Present and previous studies have shown that indomethacin, protein synthesis inhibitors, fluoride, calmodulin antagonists, TMB-8 (an intracellular $\mathrm{Ca}^{2+}$ antagonist), 
EGTA, and lack of extracellular $\mathrm{Ca}^{2+}$ inhibit PG output from Day-15 guinea-pig endometrium in culture (Riley \& Poyser, 1987a, b, 1989), indicating that the culture technique used is particularly sensitive for detecting the various ways in which endometrial PG synthesis can be inhibited. Consequently, it appears that the anti-luteolytic factor secreted by the guinea-pig conceptus which inhibits endometrial PGF-2 $\alpha$ synthesis in this species (see Poyser, 1984) is probably not related to $\alpha$-interferon and is therefore different from oTP-1.

Overall, this study has shown that endometrial PGF-2 $\alpha$ synthesis in the guinea-pig is not regulated by a toxin-sensitive G-protein, but may be regulated by a fluoride-sensitive G-protein. The anti-luteolytic factor secreted by guinea-pig conceptus is probably not related to $\alpha$-interferon and oTP-1.

This study was supported by a grant from the MRC, and a MRC Research Scholarship to C.M.L.

\section{References}

Axelrod, J., Burch, R.M. \& Jelsema, C.L. (1988) Receptor-mediated activation of phospholipase $\mathrm{A}_{2}$ via GTP-binding proteins: arachidonic acid and its metabolites as second messengers. TINS 11, 117-123.

Blatchley, F.R., Donovan, B.T., Horton, E.W. \& Poyser, N.L. (1972) The release of prostaglandins and progestin into the utero-ovarian venous blood of guinea-pigs during the oestrous cycle and following oestrogen treatment. J. Physiol., Lond. 222, 69-88.

Burch, R.M. \& Axelrod, J. (1987) Dissociation of bradykinin-induced prostaglandin formation from phosphatidylinositol turnover in Swiss $3 \mathrm{~T} 3$ fibroplasts: Evidence for $\mathrm{G}$ protein regulation of phospholipase $\mathrm{A}_{2}$. Proc. natn Acad. Sci. USA 84, 6374-6378.

Burch, R.M., Luini, A. \& Axelrod, J. (1986) Phospholipase $\mathrm{A}_{2}$ and phospholipase $\mathrm{C}$ are activated by distinct GTP-binding proteins in response to $\alpha_{1}$ adrenergic stimulation in FRTL5 thyroid cells. Proc. natn. Acad. Sci. USA 83, 7201-7205.

Burch, R.M., Jelsena, C. \& Axelrod, J. (1988) Cholera toxin and pertussis toxin stimulate prostaglandin $\mathrm{E}_{2}$ synthesis in a murine macrophage cell line. $J$. Pharmac. exp. Therap. 244, 765-773.

Burgoyne, R.D., Cheek, T.R. \& O'Sullivan, A.J. (1987) Receptor activation of phospholipase $A_{2}$ in cellular signalling. TIBS 12, 332-333.

Charpigny, G., Reinaud, P., Huet, J.-C., Guillomot, M., Charlier, M., Pernollet, J.-C. \& Martal, M. (1988) High homology between a trophoblastic protein (trophoblastin) isolated from ovine embryo and $\alpha$-interferons. FEBS Lett. 288, 12-16.

Downing, I. \& Poyser, N.L. (1983) Estimation of phospholipase $\mathrm{A}_{2}$ activity in guinea-pig endometrium on days 7 and 16 of the estrous cycle. Prostaglandins, Leuk. \& Med. 12, 107-117.

Fincher, K.B., Bazer, F.W., Hansen, P.J., Thatcher, W.W. \& Roberts, R.M. (1986) Proteins secreted by the sheep conceptus suppress induction of uterine prostaglandin F-2 $\alpha$ release by oestradiol and oxytocin. J. Reprod. Fert. 76, 425-433.

Horton, E.W. \& Poyser, N.L. (1976) Uterine luteolytic hormone: a physiological role for prostaglandin $\mathrm{F}_{2 a}$. Physiol. Rev. 56, 559-561.
Imakawa, K., Anthony, R.V., Kazemi, M., Marotti, K.R., Polites, H.G. \& Roberts, R.M. (1987) Interferon-like sequence of ovine trophoblast protein secreted by embryonic trophectoderm. Nature, Lond. 330, 377-379.

Jeremy, J.Y. \& Dandona, P. (1988) Fluoride stimulates in vitro vascular prostacyclin synthesis: interrelationships of $\mathrm{G}$ proteins and protein kinase C. Eur. $J$. Pharmac. 146, 279-284.

Leaver, H.A. \& Poyser, N.L. (1981) Distribution of arachidonic acid and other fatty acids in the lipids of guinea-pig uterus and plasma in relation to uterine prostaglandin synthesis. J. Reprod. Fert. 61, 265-271.

Nakashima, S., Nagata, K., Ueeda, K. \& Nozawa, Y. (1988) Stimulation of arachidonic acid release by guanine nucleotide in saponin-permeabilized neutrophils: evidence for involvement of GTP-binding protein in phospholipase $\mathrm{A}_{2}$ activation. Archs Biochem. Biophys. 261, 375-383.

Ning, A.C.W.S. \& Poyser, N.L. (1984) Further studies on the control of arachidonic acid turnover in guinea-pig endometrium in relation to prostaglandin production. Prostaglandins, Leuk.\& Med. 16, 285-302.

Ning, A.C.W.S., Leaver, H.A. \& Poyser, N.L. (1983) Arachidonic acid uptake into and release from guinea-pig endometrium in vitro on days 7 and 15 of the oestrous cycle. Prostaglandins, Leuk. \& Med. 10, $369-380$.

Pirotton, S., Erneux, C. \& Boeynaems, J.M. (1987) Dual role of GTP-binding proteins in the control of endothelial prostacyclin. Biochem. Biophys. Res. Commun. 147, 1113-1120.

Poyser, N.L. (1972) Production of prostaglandins by the guinea-pig uterus. J. Endocr. 54, 147-159.

Poyser, N.L. (1979) Effect of actinomycin D on uterine prostaglandin production and oestrous cycle length in guinea-pigs. J. Reprod. Fert. 56, 559-565.

Poyser, N.L. (1981) Prostaglandins in Reproduction. John Wiley \& Sons Ltd, Chichester.

Poyser, N.L. (1983) Effect of treating ovariectomized guinea-pigs with estradiol and progesterone on basal and A23187-stimulated release of prostaglandins from the uterus superfused in vitro. Prostaglandins, Leuk. \& Med. 11, 345-360. 
Poyser, N.L. (1984) Prostaglandin production by the early pregnant guinea-pig uterus in relation to implantation and luteal maintenance, and the effect of oestradiol. J. Reprod. Fert. 72, 117-127.

Poyser, N.L. (1987) Effects of various factors on prostaglandin synthesis by the guinea-pig uterus. $J$. Reprod. Fert. 81, 269-276.

Riley, S.C. \& Poyser, N.L. (1987a) Prostaglandin production by the guinea-pig endometrium: is calcium necessary? J. Endocr. 113, 463-471.

Riley, S.C. \& Poyser, N.L. (1987b) Effects of oestradiol, progesterone, hydrocortisone and oxytocin on prostaglandin output from the guinea-pig endometrium maintained in tissue culture. Prostaglandins 34, $535-552$.

Riley, S.C. \& Poyser, N.L. (1989) Is protein synthesis necessary for prostaglandin production by guinea-pig endometrium? J. Reprod. Fert. 86, 73-89.

Salamonsen, L.A., Stuchbery, S.J., O'Grady, C.M., Godkin, J.D. \& Findlay, J.K. (1988) Interferon- $\alpha$ mimics effects of ovine trophoblast protein 1 on prostaglandin and protein secretion by ovine endometrial cells in vitro. J. Endocr. 117, R1-R4.

Stewart, H.J., McCann, S.H.E., Barker, P.J., Lee, K.E., Lamming, G.E. \& Flint, A.P.F. (1987) Interferon sequence homology and receptor binding activity of ovine trophoblast antiluteolytic protein. $J$. Endocr. 115, R13-R15.

Stewart, H.J., McCann, S.H.E., Northrop, A.J., Lamming, G.E. \& Flint, A.P.F. (1989) Sheep antiluteolytic interferon: cDNA sequence and analysis of mRNA levels. J. molec. Endocr. 2, 65-70.

Wang, J., Kester, M. \& Dunn, M.J. (1988) Involvement of a pertussis toxin-sensitive G-protein-coupled phospholipase $A_{2}$ in lipopolysaccharide-stimulated prostaglandin $\mathrm{E}_{2}$ synthesis in cultured rat mesanglial cells. Biochem. Biophys. Acta 963, 429435.

Received 9 October 1989 